\title{
OMAN ELÄMÄNSÄ INSINÖÖRIT
}

\section{Suuntaa ja sykettä oppimiseen, toim. Tarja Surakka ja Katri Poutanen. Opetus 2000 WSOY 1995. $210 \mathrm{~s}$.}

Kansalais- ja työväenopistojen liiton (KTOL:n) ja Aikuiskoulutuksen maailma-lehden järjestämien vuoden 1995 aikuisopettajapäivien seminaarikirja, joka on samalla KTOL:n toinen vuosikirja, on eräänlainen aikuiskouluttajan työkalupakin uutuusvälineitten esittely. Sieltä löytyy arvojen hajoittamisen välineeksi dialoginen kirjoittaminen, onnistumiseen auttava menestyskierteen ideointimetodi, tavoitetietoisen positiivisen ajattelun metodi, ideoinnin systematisoiva kriteeritaraski, arviointia koskevaa asiaa ja muutoksen tekemisessä auttava yksilöskenaario.

Riitta Suurta ammentaa arvojen harjoittamisen metodinsa vanhoista ja syvistä lähteistä kuten Platonin ja Aristoteleen ajattelusta ja meditaation perinteestä. Hän toteaa, että tietoa ei voi hallita tiedolla vaan arvoilla ja valinnoilla. Hän hakee näkökulmaa suurilta kreikkalaisilta filosofeilta osoittaakseen, että voi olla erilaisia todellisuuskäsityksiä ja että kannattaa kysyä asioita, joita on pitänyt itsestään selvinä. Hän tuomitsee tavanomaisen arvojen käsitteellistämisen tapana, jossa arvot muuttuvat samankaltaisiksi kuin vain juhlapäivinä esille otettavat pöytähopeat, siis kaappiarvoiksi. Oikeampi tie on tiedostaa omat arvonsa ja viedä ne käytäntöön, jolloin löytyy eettisyys oman ajattelun ja toiminnan pohjana. Tähän päästään dialogisen kirjoittamisen menetelmällä.

Dialogisen kirjoittamisen menetelmässä on olennaista intuition ja hiljaisuuden harjoittaminen: sisäisestä hiljaisuudesta syntyy tila, jossa ihminen on välittömästi tajuamisen tilassa eli yhteydessä siihen niitä hän tosiasiallisesti kokee. Vastaukset omiin kysymyksiin löytyvät intuitiivisesti omasta tajunnasta. Ihminen kysyy ja vastaa itse. Vastaukset synnyttävät uusia kysymyksiä. Olennaista on myös harjoitus: kun kirjoittaminen on antanut jonkin vastauksen tai toimintaohjeen, sitä on myös harjoitettava käytännössä. Silloin oma etiikka alkaa muotoutua. Ihmistä muuttavat vain harjoittaminen, kokemus ja oivallus. Dialoginen kirjoittaminen sopii myös ryhmän työvälineeksi.

Mielenkiintoista! Postmodernina aikanamme jotkut syvät virrat ovat tulvimassa uudelleen näkyviin. Valistuksen rationalismin syrjään työntämä meditaatio ja hiljaisuuden viljely on kokemassa parhaillaan renessanssia uskonnollisessa elämässä. Ihmiset hakevat syvyysulottuvuutta; dialogisen kirjoittamisen metodi näyttää olevan eräs tekniikka, joka hyödyntää hiljaisuuden voimaa. Ihmisen hiljaisen tietoisuuden kerrostumaa tangeerataan intuitiivisen löytämisen verran; hiljaisuuden ja mystiikan muut ulottuvuudet, kaikkeuselämys ja olevaisen yhteyden tajuaminen jätetään sensijaan sivuun.

Kiinnostava on myös menetelmän hyve-eettinen perusidea. Hyve-etiikka on sekin nousussa, se onkin varmasti modernin autonomisen ihmisen luonnollinen eettinen malli. Ihminen on eettinen subjekti. Intuitio ei kuitenkaan riitä enää silloin, kun etiikasta ryhdytään keskustelemaan muiden ihmisten kanssa. Eettisessä keskustelussa tarvitaan myös rationaalista argumentaatiota. joka tapauksessa Riitta Suurlan kirjoitukseen kannattaa ehdottomasti tutustua ja myös panna se harjoitukseen.

Timo Lampikoski opettaa onnistumaan esittelemällä menestyskierteen ideointia, menestymisen avaintekijöitä ja ydinpätevyyttä menestymisen perustana. Ydinpätevyyden käsittely on erityisen antoisa. Traditionaalisen koulutuksen ongelmana on irrallisten, sirpaleisten tietojen ja taitojen opettaminen ilman vankkaa perustaa. Ydintaidot kirjoittaja asettaa neljälle elämisen ulottuvuudelle, jotka ovat fyysinen, henkinen, uskonvoimainen ja sosiaalinen. Näille alueille sijoittuvien perustaitojen hallinta muodostaa ihmisen ydinpätevyyden. 
Kirjoittajan mielestä elämässä onnistumisen kannalta keskeistä on tiedostaa oman elämänsä tarkoitus, päämäärät ja arvot. Menestyminen edellyttāä ydintaitojen lisäksi päämäärätietoisuutta, synergiaa, omien vahvuuksien kehittämistä ja menestyksen yläkierteen laukaisemista niitä se sitten onkin, ja lopuksi vielä nostetta kehittymisen spiraaliin, Kirjoittaja pohtii myös menestymisen luonnetta. Mitä lopulta on menestyminen elämässä? Hän päätyy ihmisyyteen, ei niinkään siihen mitä saavutamme, vaan siihen mitä me olemme ihmisinä, mitä annamme itsestämme muille ja miten autamme muita onnistumaan.

Leena Vikeväinen-Tervonen käsittelee positiivista ajattelua ja minäkuvaa tehokkaan oppimisen ja opettamisen mahdollistajina. Marja-Leena Koppinen käsittelee oppimisen arvioinnin problematiikkaa ja Tarja Meristö muutoksen tekemistä yksilö--skenaariotyöskentelyn avulla. Carola Lindholm on kirjoittanut lukujen väliin hauskan kehystarinan.

Kiinnostavan omaperäinen n Erkki Ruotsin kriteeritaraski-järjestelmien esittely: päämäärätietoisen ja numeraalisuuteen nojaavan insinööritaidon sekä humanistishenkisen luovan työskentelyn yhteensulattaminen tässä menetelmässä on kutittava yhdistelmä. Tekisi mieli kokeilla.

Ruotsi panee kaiken olennaisen hyvin näkyviin, mutta lukijan on silti vaikea tulla hullua hurskaammaksi: montako tuntia tarvittaisikaan, että metodi todella aukenisi? Mitä oikeastaan ovatkaan IPO-prosessi, työn painoarvo, painottamaton neitseellinen piste, painoarvolla painotettu piste tai hankekriteerin toteutumispisteet? Miten tässä kaikki oikein sijoittuukaan prosessin selkäruotoon, miten taas Kriteeritaraski ja Kritar-prosessi suhteutuvatkaan toisiinsa? Selkeämmältä tuntuu ajatus hankkeen toteutuksen osatöiden määrittelystä viiden vaihtoehdon puitteissa eli määrittelemällä työlle (1) rohkea, (2) antautuva, (3) sovinnainen. (4) innovatiivinen ja (5) koostetyyppinen toteutustapa. Tätä täytyy opiskella lisää!

Käytännön aikuiskouluttajalle kirja on hyvä johdatus toimivaan metodiikkaan. Työkalupakkiinsa voisi koettaa omaksua ainakin jonkin näistä välineistä. Yhteistäkin niillä on. Kaikki ne näyttävät tähtäävän parempaan oman elämän hallintaan, menestymiseen ja kehitykseen, kaiken kaikkiaan johonkin positiiviseen positiivisella tavalla. Ihmiselämä näyttäytyy niiden valossa projektina, jota voi hallita ja ohjailla. Ihminen on oman onnensa seppä tai insinööri. Ihmiselämän katoavaisuus, raadollisuus ja vajavaisuus peittyvät optimismin alle - ja onhan tietysti mahdollista, että ihmiselle joskus käykin niinkuin hän toivoo ja uskoo. 